\title{
Correction to: The epidemiologic impact and cost-effectiveness of new tuberculosis vaccines on multidrug-resistant tuberculosis in India and China
}

Chathika K. Weerasuriya ${ }^{1 *}$, Rebecca C. Harris ${ }^{1,2}$, C. Finn McQuaid ${ }^{1}$, Fiammetta Bozzani ${ }^{3}$, Yunzhou Ruan ${ }^{4}$, Renzhong Li ${ }^{4}$, Tao Li ${ }^{4}$, Kirankumar Rade ${ }^{5}$, Raghuram Rao ${ }^{6}$, Ann M. Ginsberg ${ }^{7,8}$, Gabriela B. Gomez ${ }^{3,9 \dagger}$ and Richard G. White ${ }^{1+}$

Correction to: BMC Medicine 19, 1-13 (2021)

https://doi.org/10.1186/s12916-021-01932-7

The original article contained errors in the Abstract which have all since been corrected.

\begin{abstract}
Author details
${ }^{1}$ TB Modelling Group, TB Centre and Centre for the Mathematical Modelling of Infectious Diseases, Department of Infectious Disease Epidemiology, Faculty of Epidemiology \& Population Health, London School of Hygiene and Tropical Medicine, London, UK. ${ }^{2}$ Currently employed at Sanofi Pasteur, Singapore, Singapore. ${ }^{3}$ Department of Global Health and Development, Faculty of Public Health \& Policy, London School of Hygiene and Tropical Medicine, London, UK. ${ }^{4}$ Chinese Centre for Disease Control and Prevention, Beijing, China. ${ }^{5}$ World Health Organisation, New Delhi, India. ${ }^{6}$ National Tuberculosis Elimination Programme, New Delhi, India. ${ }^{7}$ International AIDS Vaccine Initiative, New York, USA. ${ }^{8}$ Current Affiliation: Bill and Melinda Gates Foundation, Washington, DC, USA. ${ }^{9}$ Currently employed at Sanofi Pasteur, Lyon, France.
\end{abstract}

Published online: 01 March 2022

The original article can be found online at https://doi.org/10.1186/s12916021-01932-7.

\footnotetext{
*Correspondence: c.weerasuriya@lshtm.ac.uk

${ }^{\dagger}$ Gabriela B. Gomez and Richard G. White contributed equally to this work.

${ }^{1}$ TB Modelling Group, TB Centre and Centre for the Mathematical Modelling of Infectious Diseases, Department of Infectious Disease Epidemiology, Faculty of Epidemiology \& Population Health, London School of Hygiene and Tropical Medicine, London, UK

Full list of author information is available at the end of the article
}

(C) The Author(s) 2022. Open Access This article is licensed under a Creative Commons Attribution 4.0 International License, which permits use, sharing, adaptation, distribution and reproduction in any medium or format, as long as you give appropriate credit to the original author(s) and the source, provide a link to the Creative Commons licence, and indicate if changes were made. The images or other third party material in this article are included in the article's Creative Commons licence, unless indicated otherwise in a credit line to the material. If material is not included in the article's Creative Commons licence and your intended use is not permitted by statutory regulation or exceeds the permitted use, you will need to obtain permission directly from the copyright holder. To view a copy of this licence, visit http://creativecommons.org/licenses/by/4.0/. The Creative Commons Public Domain Dedication waiver (http://creativeco mmons.org/publicdomain/zero/1.0/) applies to the data made available in this article, unless otherwise stated in a credit line to the data. 